\title{
Leaf chlorophyll content in North Sulawesi (Indonesia) local rice cultivars subjected to polyethylene glycol (PEG) 8000-induced water deficit at the vegetative phase
}

\author{
SONG AI NIO ${ }^{1, \vartheta}$, MONALISA PIRADE ${ }^{1, \vee \vartheta}$, DANIEL PETER MANTILEN LUDONG ${ }^{2, \vee \vee \vartheta}$ \\ ${ }^{1}$ Department of Biology, Faculty of Mathematics and Natural Sciences, University of Sam Ratulangi. Jl. Kampus Unsrat Manado 95115, North Sulawesi, \\ Indonesia. Tel./fax.+62-431-864386, `email: niosongai@unsrat.ac.id, "• email: monalisa.pirade@ gmail.com \\ ${ }^{3}$ Department of Agricultural Technology, Faculty of Agriculture, Universitas Sam Ratulangi. Kampus Unsrat, Manado 95115, North Sulawesi, Indonesia. \\ •vemail: mantilenpd@yahoo.com
}

Manuscript received: 6 July 2019. Revision accepted: 8 August 2019

\begin{abstract}
Nio SA, Pirade M, Ludong DPM. 2019. Leaf chlorophyll content in North Sulawesi (Indonesia) local rice cultivars subjected to polyethylene glycol (PEG) 8000-induced water deficit at the vegetative phase. Biodiversitas 20: 2462-2467. Climate change can result in drought stress in the environment and this condition reduces rice production. Polyethylene glycol (PEG) is used to induce water deficit, because it is able to decrease water potential in the solution. The present study aimed to evaluate the physiological response of North Sulawesi local rice (cvs. Superwin, Ombong, Burungan, and Temo) to PEG 8000-induced water deficit based on the leaf chlorophylls ( $\mathrm{a}, \mathrm{b}$ and total chl.) content at the vegetative phase. The results of this study showed that PEG 8000-induced water deficit with media water potential (WP) -0.25 and $-0.5 \mathrm{MPa}$ decreased the content of leaf total chlorophyll and leaf chlorophyll a. The longer treatment period could reduce the contents of leaf total chlorophyll, chlorophyll a and chlorophyll b. The content of leaf chlorophyll total and chlorophyll a were potential physiological indicators for North Sulawesi local rice response to PEG 8000-induced water deficit.
\end{abstract}

Keywords: Chlorophyll, drought, North Sulawesi local rice, vegetative

\section{INTRODUCTION}

The drought stress caused by climate change limits the world's food production because of the uncertain water availability during this stress period (Tao et al. 2006). Drought stress in the agricultural area can reduce agricultural production until $50 \%$ or even result in crop failure if the drought condition becomes worse (Wood 2005; Sopandie 2013). Drought can be primary or secondary stress. As primary stress, drought stress is caused by the limitation of water availability in the plant media and as secondary stress, drought stress is induced by cold, frozen, hot or high salinity condition (Tal 1983). Drought stress in this present study was related to the reduction of water supply around the plant root zone.

Rice (Oryza sativa L.) is an important crop plant as it is one of the staple foods for most of world's inhabitants, especially in continental Asia, including Indonesia (Indraswati et al. 2015). North Sulawesi has potential to be the center of rice cultivation, because Sulawesi is the third biggest rice producer in Indonesia and supports $10 \%$ of national rice production. The biodiversity of potential North Sulawesi local rice cultivars, such as Temo, Ombong, Burungan, dan Superwin, will be useful for guaranteeing the availability of crop plants during dry season as a result of the uncertainties due to climate change. The evaluation of drought resistance in these four local rice cultivars of North Sulawesi, is required to be intensively conducted to increase rice production in North Sulawesi.

Chlorophyll content that is related to the photosynthesis rate is one of the physiological characteristics to evaluate the effect of water deficit on the growth and production of crops ( $\mathrm{Li}$ et al. 2006). The content of leaf chlorophyll is able to indicate photosynthetic capability in plant tissues (Hassanzadeh et al. 2009). One of the plant responses to water deficit is the decrease of leaf chlorophyll content. The reduction of water availability in plants will inhibit the synthesis of leaf chlorophyll and even disintegrate the chlorophyll because of the decrease of the photosynthesis rate and the increase of temperature and the transpiration rate (Nio and Banyo 2011). For example, chlorophyll content per unit leaf area in young Brazilian green dwarf coconut (Cocos nucifera L.) decreased under water deficit (Gomes 2008), the leaf total chlorophyll content in ginger (Zingiber officinale L.) decreased at 7 days after water deficit (Nio 2011) and leaf chlorophyll content in vanilla (Vanilla planifolia Andrews) declined when 20\% PEG 6000 was added to the culture media (Jamil et al. 2015).

Polyethylene glycols (PEG) with molecular weight of $6000 \mathrm{~g} \mathrm{~mol}^{-1}$ and above is appropriate to induce water deficit in plants because these water-soluble polymers are non-ionic, non-toxic, able to decrease the water potential in the media without penetrating intact plant tissue (Chazen et al. 1995). The larger molecular weight of the PEG, the smaller its possibility to be absorbed by the plant cells and this PEG molecule acted only to decrease water potential in the media and almost had no poisonous effect to the plants (Pratiwi 2016). This characteristics of PEG is useful for the simulation of water potential reduction in the medium and is often used for evaluating plant resistance under water 
deficit (Nio et al. 2018), such as PEG 6000 treatment in Solanum melongena L. (Sinaga 2015) and Arachis hypogaea L. (Rahayu et al. 2006), and also PEG 8000 in Triticum aestivum L. (Nio et al. 2018). PEG 8000 was used in this study and there were three kinds of media water potential after adding this substance, i.e $0,-0.25$ and -0.5 MPa (Ballo et al. 2012). The drought resistance of North Sulawesi local rice under PEG 8000-induced water deficit at the vegetative phase based on the leaf chlorophyll content (total, a and b) were evaluated in this study.

\section{MATERIALS AND METHODS}

\section{Procedures}

This study was carried out from November 2017 until January 2018 in the greenhouse in the Tingkulu District, Manado - North Sulawesi and in the Laboratory Ecology, Biology Department, Faculty of Mathematics and Natural Sciences, Sam Ratulangi University. This study consisted of four rice cultivars, three water deficit-induced PEG 8000 treatments, three sampling times with three replicates. The four cultivars of North Sulawesi local rice used in this study were Temo, Ombong, Burungan, and Superwin (Nio et al. 2018). The water deficit-induced PEG 8000 treatments were water potential (WP) medium $0,-0.25$ dan $-0.5 \mathrm{MPa}$ by adding 0,135 and $198 \mathrm{~g}$ PEG 8000 in $1 \mathrm{~L}$ basal medium solution (modification Nio et al. 2011). The basal medium in this study was AB Mix Minimax ${ }^{\circledR}$ hydroponics nutrition solution that contained calcium nitrate $\left(\mathrm{Ca} \quad\left(\mathrm{NO}_{3}\right)_{2}\right)$, potassium nitrate $\left(\mathrm{KNO}_{3}\right)$, potassium dihydrogen phosphate $\left(\mathrm{KH}_{2} \mathrm{PO}_{4}\right)$, ammonium sulfate $\left.\left(\mathrm{NH}_{4}\right)_{2} \mathrm{SO}_{4}\right)$, potassium sulfate $\left(\mathrm{K}_{2} \mathrm{SO}_{4}\right)$, magnesium sulfate $\left(\mathrm{MgSO}_{4}\right)$, and chelated nutrient mixture. Water deficit treatments were medium with WP -0.25 and $-0.5 \mathrm{MPa}$ that were categorized as medium and high-level stress, respectively (Castillo et al. 2007).

Rice seeds were selected by soaking them in water for two hours to obtain the submerged seeds as good quality seeds. The selected seeds were three times surfacedsterilized using $0.1 \% \mathrm{NaClO}$ solution and each time for 2 minutes, and then the seeds were rinsed with water. The seeds were grown in a tray filled with soil mixed with NPK fertilizer ( $6 \mathrm{~g}$ NPK fertilizer in $7 \mathrm{~kg}$ soil) and the media was watered until field capacity. All of the trays with the seeds were covered with wet paper until the seeds germinated. The germinated seeds were maintained by watering them with $0.1 \%$ Gandasil $\mathrm{D}^{\circledR}$ (fertilizer) solution until the plants reached four fully expanded leaf stage (modification Nio and Ludong 2014).

Water deficit treatment was applied for 12 hours by growing the plants in the PEG 8000 solution with WP 0, 0.25 and $-0.5 \mathrm{MPa}$. Before the treatment commenced, the whole plants were rinsed and four plants were grown in the $100 \mathrm{~mL}$ hydroponic solution in a plastic container (volume $240 \mathrm{~mL}$ ). All containers with the plants were put on the orbital shaker (50 opm) under light (2880 lumen cool white light for 12 hours per day) in $25^{\circ} \mathrm{C}$ room for a week. The leaves were sampled three times (Table 1), i.e. 0 (before the treatment commenced), 6 and 12 hours after treatment (modification Nio et al. 2011).
Leaf chlorophyll was extracted using 95\% ethanol and the contents of total chlorophyll, chlorophyll a and b were measured using spectrophotometer SP-3000 nano Optima ${ }^{\circledR}$ at $\lambda 649$ and $665 \mathrm{~nm}$ (Tjolleng et al. 2019).

\section{Data analysis}

Mean and standard errors were calculated using Microsoft Office Excel 2010. Data of factorial experiment in Randomized Block Design were analyzed using SPSS 16. Analysis of variance (ANOVA) followed by Duncan's Multiple Range Test (DMRT) 5\% was used to identify the significant differences and interactions among treatments (where $\mathrm{p}<0.05$ ).

\section{RESULTS AND DISCUSSION}

The plants required appropriate environmental conditions for their growth and development, however, the change in the environmental conditions could decrease rice productivity. The phenomenon indicated that each plant had limiting factors and tolerance capabilities in their response to the changing environment (Purwadi 2011). Chlorophyll content has a significant effect on photosynthesis capacity (Hassanzadeh et al. 2009). PEG with molecular weight of $6000 \mathrm{~g} \mathrm{~mol}^{-1}$ and above are often used to induce water deficit in plants. Water deficit decreased the content of leaf chlorophyll and it could be used as an indicator of drought tolerance in plants (Banyo et al. 2013). This study evaluated the chlorophyll content in North Sulawesi local rice cultivars (Superwin, Ombong, Burungan, dan Temo) as response to PEG 8000-induced water deficit at the vegetative stage.

Table 1. Sampling time of leaves in PEG 8000 solution in the experiment

\begin{tabular}{|c|c|c|c|}
\hline \multirow{2}{*}{ PEG (MPa) } & \multicolumn{3}{|c|}{ Hours } \\
\hline & $\mathbf{0}$ & 6 & 12 \\
\hline 0 & $\checkmark$ & $\checkmark$ & $\checkmark$ \\
\hline-0.25 & & $\checkmark$ & $\checkmark$ \\
\hline-0.50 & & $\checkmark$ & $\checkmark$ \\
\hline
\end{tabular}

Table 2. The content of total chlorophyll, chlorophyll a and $\mathrm{b}$ in rice leaves at 0,6 and 12 hours after PEG 8000 induced water deficit (WP $0,-0.25$ and $-0.5 \mathrm{MPa}$ ). The data represented the average of cvs. Superwin, Burungan, Ombong, and Temo. Values are mean $\pm \mathrm{SE}(\mathrm{n}=3)$

\begin{tabular}{cccc}
\hline Treatment & $\begin{array}{c}\text { Total } \\
\text { chlorophyll } \\
\left(\mathbf{m g ~ L}^{-1}\right)\end{array}$ & $\begin{array}{c}\text { Chlorophyll a } \\
\left(\mathbf{m g ~ L}^{-1}\right)\end{array}$ & $\begin{array}{c}\text { Chlorophyll b } \\
\left(\mathbf{m g ~ L}^{-1}\right)\end{array}$ \\
\hline PEG (MPa) & & & \\
0 & $8.24 \pm 0.47^{\mathrm{b}}$ & $4.88 \pm 0.25^{\mathrm{b}}$ & \\
-0.25 & $6.48 \pm 0.70^{\mathrm{a}}$ & $3.27 \pm 0.41^{\mathrm{a}}$ & \\
-0.50 & $6.33 \pm 0.71^{\mathrm{a}}$ & $3.41 \pm 0.39^{\mathrm{a}}$ &
\end{tabular}

Time (hours)

\begin{tabular}{cccc}
0 & $9.26 \pm 0.61^{\mathrm{b}}$ & $5.13 \pm 0.15^{\mathrm{b}}$ & $3.79 \pm 0.26^{\mathrm{b}}$ \\
6 & $5.99 \pm 0.44^{\mathrm{a}}$ & $3.22 \pm 0.29^{\mathrm{a}}$ & $2.70 \pm 0.22^{\mathrm{a}}$ \\
12 & $5.80 \pm 0.66^{\mathrm{a}}$ & $3.21 \pm 0.47^{\mathrm{a}}$ & $2.70 \pm 0.28^{\mathrm{a}}$ \\
\hline
\end{tabular}

Note: Significant differences $(\mathrm{P}<0.05)$ amongst the treatments by DMRT were indicated by different letters in the same column 
The content of leaf total chlorophyll as response to PEG 8000-induced water deficit

Chlorophyll is a pigment found in plants that conduct photosynthesis (Hendriyani and Setiari 2009). Water deficit from low to the high levels decreased photosynthesis rates in plants (Salisbury and Ross 1992). Chlorophyll biosynthesis closely related to the photosynthesis is very sensitive to the water deficit.

The result of ANOVA analysis revealed that only PEG concentration and its treatment duration resulted in significant differences in the content of leaf total chlorophyll (Figure 1; Table 2). Based on the Duncan's Multiple Range Test (DMRT) 5\%, the content of leaf total chlorophyll in PEG -0.25 MPa $\left(6.48 \mathrm{mg} \mathrm{L}^{-1}\right)$ and $-0.5 \mathrm{MPa}$ $\left(6.33 \mathrm{mg} \mathrm{L}^{-1}\right)$ were $27 \%$ and $30 \%$ lower than PEG $0 \mathrm{MPa}$ $\left(8.24 \mathrm{mg} \mathrm{L}^{-1}\right)$ respectively. The content of leaf total chlorophyll in PEG -0.25 MPa was not different from -0.5 $\mathrm{MPa}$. The content of leaf total chlorophyll at 6 and 12 hours after treatment were $54.76 \%$ and $59.83 \%$ lower than 0 hour $\left(9.26 \mathrm{mg} \mathrm{L}^{-1}\right)$, respectively. The content of leaf total chlorophyll at 6 and 12 hours after treatment were not different. A decrease in PEG 8000 concentration and a longer water deficit period, caused leaf total chlorophyll to decrease in cvs. Superwin, Burungan, Ombong, and Temo.

The decrease in the content of total chlorophyll under water deficit was also reported in some species and the decrease rate was influenced by the rate and duration of drought stress (Hassanzadeh et al. 2009). The content of total chlorophyll in long beans (Vigna sinensis L.) under watering until $50 \%$ field capacity for 3 days was $3.13 \mathrm{mg}$ $\mathrm{L}^{-1}$; whereas that in the control was $3.73 \mathrm{mg} \mathrm{L}^{-1}$ (Hendriyani and Setiari 2009). The content of total chlorophyll in ginger (Zingiber officinale L.) leaf decreased $8 \%$ at 7 days after treatment; however, it increased $9 \%$ from day 0 to 7 in well-watered plants (Nio 2011). The content of total chlorophyll in rice cv. Situ Patenggang under PEG 6000-induced-water deficit for 24 hours was $1.7 \mathrm{mg} \mathrm{L}^{-1}$ versus the control plant was $2.3 \mathrm{mg} \mathrm{L}^{-1}$ (Indraswati 2015). The content of total chlorophyll was decreased in Pistacia khinjuk and P. mutica under PEG 6000-induced drought stress (Ranjbarfordoei et al. 2000). PEG-mediated water deficit in rice reduced the content of leaf chlorophyll content (Hsu and Kao 2003). These results showed that the content of total chlorophyll could be used as an indicator of drought stress in plants, including North Sulawesi local rice cultivars.

\section{The content of leaf chlorophyll a as response to PEG 8000 -induced water deficit}

Chlorophyll a is very sensitive to soil dehydration (Farooq et al. 2009) and this pigment changes the radiation energy to chemical energy, absorbs and transfers energy to reaction center in the photosystem of photosynthesis (Sirait 2008). The evaluation of chlorophyll a content under water deficit was carried out in long beans (Hendriyani and Setiari 2009), cocoa (Prihastanti 2010), sugarcane (Cha-um et al. 2012) and grass Paspalum notatum (Maisura et al. 2015).
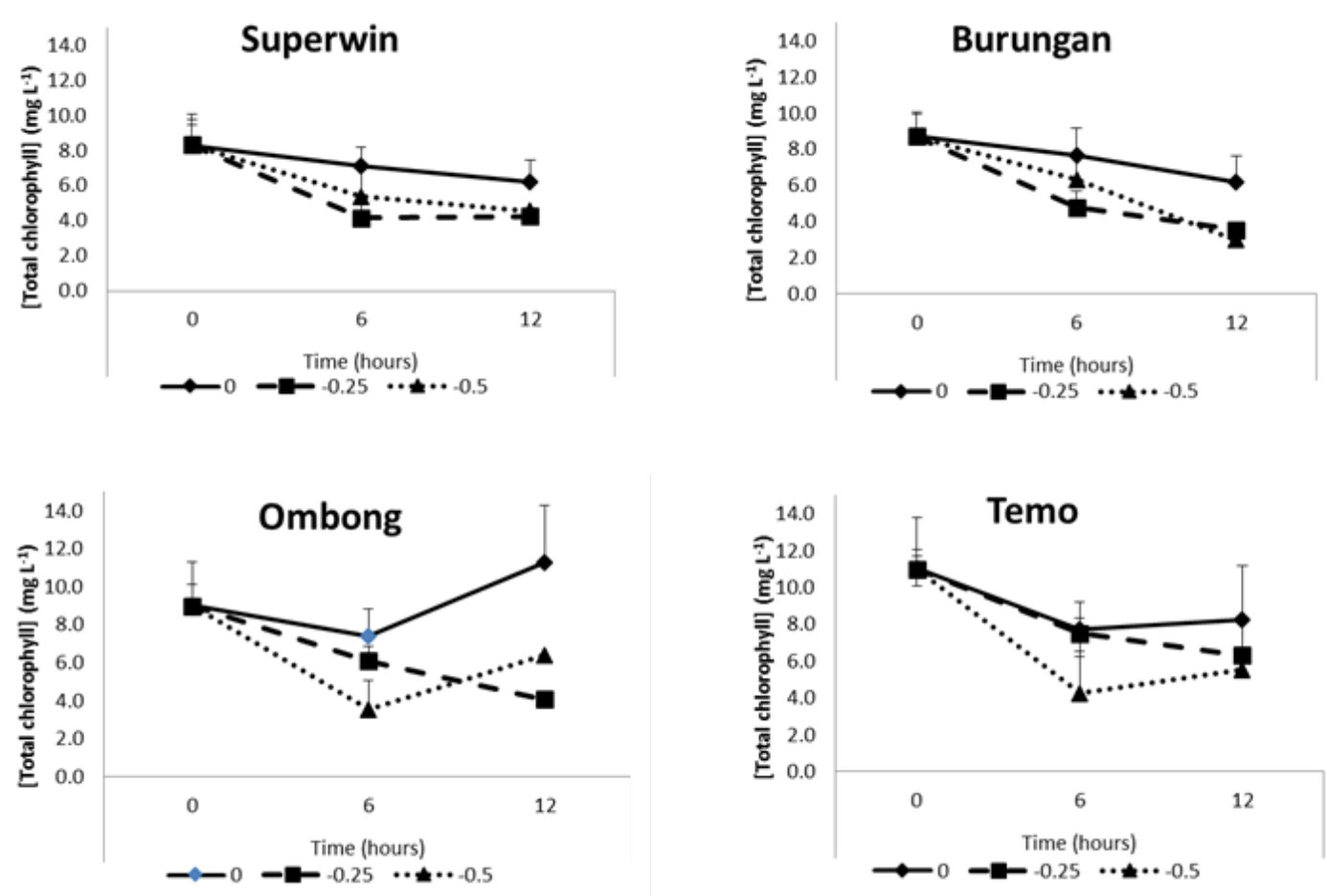

Figure 1. The content of leaf total chlorophyll $\left(\mathrm{mg} \mathrm{L}^{-1}\right)$ in rice cvs. Superwin, Burungan Ombong, dan Temo at 0,6 and 12 hours after PEG 8000 induced water deficit (WP $0,-0.25$ and $-0.5 \mathrm{MPa}$ ) 
The results of the present study showed that the content of leaf chlorophyll a in North Sulawesi local rice cultivars under PEG 8000-induced water deficit was different due to PEG concentration and length of treatment (Figure 2; Table 2). Leaf chlorophyll a contents in PEG $-0.25 \mathrm{MPa}(3.27 \mathrm{mg}$ $\left.\mathrm{L}^{-1}\right)$ and $-0.5 \mathrm{MPa}\left(3.41 \mathrm{mg} \mathrm{L}^{-1}\right)$ treatments were 37 and $41 \%$ lower than in PEG $0 \mathrm{MPa}\left(4.88 \mathrm{mg} \mathrm{L}^{-1}\right)$. Leaf chlorophyll a contents in PEG -0.25 and $-0.5 \mathrm{MPa}$ treatments were not significantly different $(\mathrm{P}>0.05)$. Leaf chlorophyll a contents decreased $59.31 \%$ and $59.81 \%$ at 6 and 12 hours after treatment, respectively, compared with 0 hour or before treatment commenced $\left(5.13 \mathrm{mg} \mathrm{L}^{-1}\right)$. Leaf chlorophyll a contents were not significantly different between 6 and 12 hours after treatment $(P>0.05)$. The lower concentrations of PEG 8000 and the longer period of water deficit decreased the content of leaf chlorophyll a in North Sulawesi local rice cvs. Superwin, Burungan, Ombong, and Temo.

Previous studies have shown that water deficit also reduced the content of leaf chlorophyll a. Leaf chlorophyll a content was 1.4 and $1.8 \mathrm{mg} \mathrm{L}^{-1}$ in long beans (Vigna sinensis L.) at 3 days of watering until $50 \%$ field capacity and control plants, respectively (Hendriyani and Setiari 2009). Drought stress decreased leaf chlorophyll a contents in 27 genotypes of sesame (Sesamum indicum L.) at the early flowering stage (Hassanzadeh et al. 2009). Leaf chlorophyll a contents in one-month-cocoa (Theobroma cacao L.) under $50 \%$ field capacity-watering was $45.69 \%$ lower than under $75 \%$ field capacity-watering (Prihastanti 2010). The level of leaf chlorophyll a in rice cv. IR 64 in PEG -0.5 and -1.0 atm were 39 and $91 \%$ lower than in PEG $0 \mathrm{~atm}$ (13.2 $\mathrm{mg} \mathrm{L}^{-1}$ ), respectively (Nio 2010). Water deficit for 14 days in sugar cane (Saccharum sp.) decreased the content of leaf chlorophyll a about $41.68 \%$ compared with the control plant (Cha-um et al. 2012). The treatment of 3week-water deficit lowered the content of leaf chlorophyll a about $45 \%$ in grass Paspalum notatum (Maisura et al. 2015). The higher concentration of PEG, resulting in lower levels of leaf chlorophyll a in peanut (Meher et al. 2018). The present study indicated that larger PEG concentration and longer duration of water deficit treatment in North Sulawesi local rice under PEG 8000-induced-water deficit decreased the content of leaf chlorophyll a. The content of leaf chlorophyll a was a potential indicator in North Sulawesi local rice under water deficit.

\section{The content of leaf chlorophyll $b$ as response to PEG 8000-induced water deficit}

Water deficit caused chlorophyll damage and reduced thylakoid function (Farooq et al. 2009). Some experiments have been conducted to evaluate the content of chlorophyll b under water deficit, such as in potato (Mescht et al. 1999), long beans (Hendriyani and Setiari 2009), cocoa (Prihastanti 2010) and rice (Banyo et al. 2013).
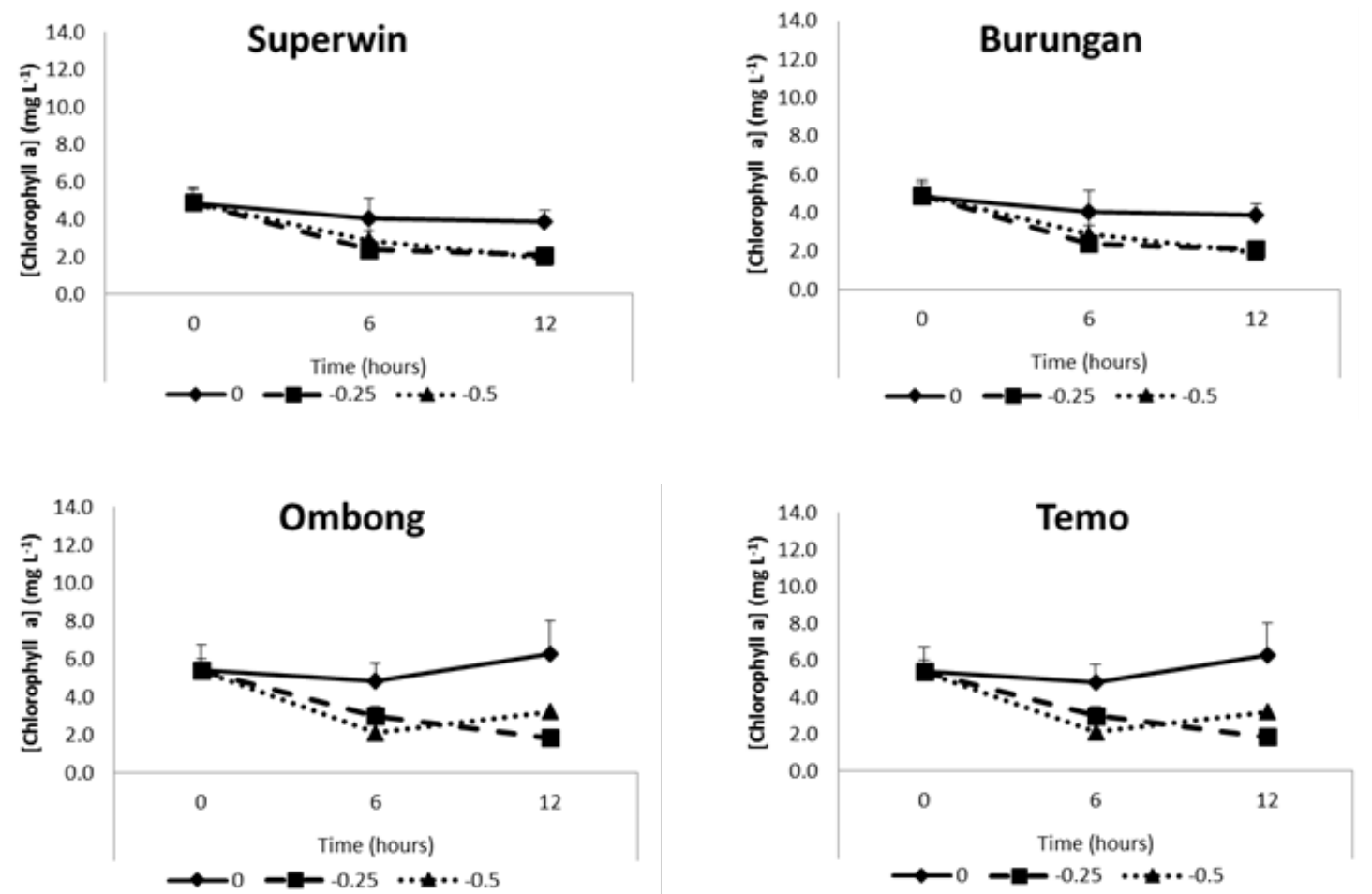

Figure 2. The content of leaf chlorophyll a $\left(\mathrm{mg} \mathrm{L}^{-1}\right)$ in rice cvs. Superwin, Burungan Ombong, dan Temo at 0,6 and 12 hours after PEG 8000 induced water deficit (WP $0,-0.25$ and $-0.5 \mathrm{MPa}$ ). 

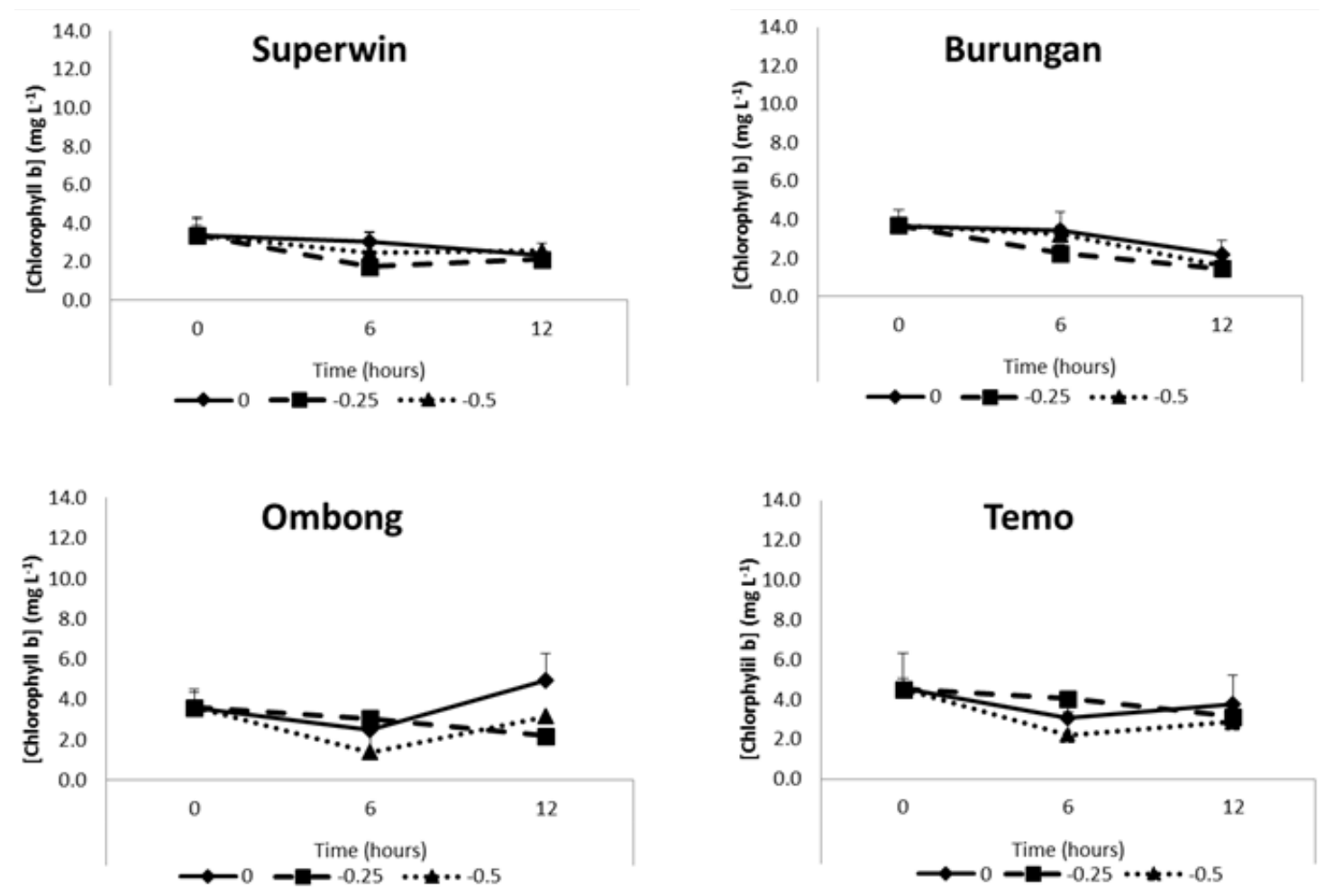

Figure 3. The content of chlorophyll $b\left(\mathrm{mg} \mathrm{L}^{-1}\right)$ in rice cvs. Superwin, Burungan Ombong, dan Temo at 0,6 and 12 hours after PEG 8000 induced water deficit (WP $0,-0.25$ and $-0.5 \mathrm{MPa}$ )

Statistical analysis using ANOVA showed that the content of leaf chlorophyll $b$ in North Sulawesi local rice cultivars under PEG 8000-water deficit was different among the treatment durations. The contents of leaf chlorophyll b at 6 hours $\left(2.70 \mathrm{mg} \mathrm{L}^{-1}\right)$ and 12 hours $(2.70$ $\left.\mathrm{mg} \mathrm{L}^{-1}\right)$ after treatment were $40.37 \%$ lower $(\mathrm{P}<0.05)$ compared to 0 hour $\left(3.79 \mathrm{mg} \mathrm{L}^{-1}\right)$. The contents of leaf chlorophyll $b$ at 6 and 12 hours after treatment were not significantly different (Figure 3; Table 2). The longer water deficit period resulted in smaller content of leaf chlorophyll b in North Sulawesi local rice cv. Superwin, Burungan, Ombong, dan Temo. The content of leaf chlorophyll $b$ in potato (Solanum tuberosum L.) decreased about $39.24 \%$ at 4 weeks after water deficit treatment compared with control plants (Mescht et al. 1999). The content of leaf chlorophyll $\mathrm{b}$ in long beans (Vigna sinensis L.) was 1.73 and $1.93 \mathrm{mg}$ $\mathrm{L}^{-1}$, respectively under control and treatment of $50 \%$-fieldcapacity water deficit for 3 days (Hendriyani and Setiari 2009). An experiment in one-year-cocoa plant showed that the content of leaf chlorophyll $b$ at one month after watering $50 \%$ field capacity was $41.58 \%$ lower than watering $75 \%$ field capacity (Prihastanti 2010). The present study showed that the content of leaf chlorophyll $b$ was not an indicator of drought tolerance in North Sulawesi local rice as discussed below.

The PEG 8000 concentration that induced water deficit and treatment period in this study resulted in different physiological response in the North Sulawesi local rice cvs. Superwin, Burungan, Ombong, and Temo. The contents of leaf total chlorophyll and chlorophyll a in PEG -0.25 and -
0.5 MPa were lower than in PEG $0 \mathrm{MPa}$. The longer treatment period could reduce the contents of leaf total chlorophyll, chlorophyll a and chlorophyll b. The present study demonstrated that chlorophyll a was more sensitive to PEG 8000-induced water deficit rather than chlorophyll $\mathrm{b}$ and the same finding was also reported in pigeon pea (Cajanus cajan L. Millsp.) by Kumar et al. (2011) and in peanut leaves by Meher et al. (2018). The contents of total chlorophyll and chlorophyll a were reduced because water deficit induced the plants to produce reactive oxygen species (ROS) such as $\mathrm{O}_{2}{ }^{-}$and $\mathrm{H}_{2} \mathrm{O}_{2}$, then followed by lipid peroxidation and chlorophyll destruction (Hassanzadeh et al. 2009). The consequence of the reduction of total chlorophyll content was a lower capacity of lightharvesting that was required for the photosynthesis process (Kumar et al. 2011).

It was concluded that the contents of total leaf chlorophyll and chlorophyll a were potential indicators of drought tolerance in North Sulawesi local rice cvs. Superwin, Burungan, Ombong, and Temo. Further detailed experiments should be conducted to determine which North Sulawesi local rice cultivars are drought tolerant ones.

\section{ACKNOWLEDGEMENTS}

The authors are grateful to Dr. Agus Darwanto for his useful suggestions on this manuscript and special thanks to Parluhutan Siahaan for assistance during the research. 


\section{REFERENCES}

Ballo M, Nio SA, Pandiangan D, Mantiri F. 2012. Morphological response of rice to water deficit at the germination phase. J Bioslogos 2 (2): 88-95. [Indonesian]

Banyo Y, Nio SA, Siahaan P, Tangapo A. 2013. Leaf chlorophyll content in rice under polyethylene-glycol-induced water deficit. J Ilmiah Sains 13 (1): 1-8. [Indonesian]

Castillo E, Tuong TP, Ismail A, Inibushi K. 2007. Response to salinity in rice: Comparative effect of osmotic and ionic stresses. Plant Prod Sci 10 (2): $159-170$

Cha-um S, Wangmoon S, Mongkolsiriwatana C, Ashraf M, Kirdmanee C. 2012. Evaluating sugarcane (Saccharum sp.) cultivars for water deficit tolerance using some key physiological markers. J Plant Biotechnol 29 (5): 431-439.

Chazen O, Hartung W, Neumann PM. 1995. The different effect of PEG 6000 and $\mathrm{NaCl}$ on leaf development are associated with differential inhibition of root water transport. Plant Cell Environ 18 (7): 727-735.

Farooq M, Wahid A, Kobayashi N, Fujita D, Basra SM. 2009. Plan drought stress: effect mechanisms and management. Agron Sustain Dev 29: 185-212. https: //doi.org/10.1051/agro: 2008021

Gomes FB, Olivia MA, Nielke MS, Almeida AF, Leite HG, Aquine LA 2008. Photosynthetic limitations in leaves of young Brazilian green dwarf coconut (Cocos nucifera L.) palm under well-watered conditions and recovering from drought stress. Environ Exp Bot 62: 195-204.

Hassanzadeh M, Ebadi A, Panahyan-e-Kivi M, Eshghi AG, Jamaati-eSomarin, Saeidi M, Zabihi-e-Mahmoodabad R. 2009. Evaluation of drought stress on relative water content and chlorophyll content of sesame (Sesamum indicum L.) genotypes at early flowering stage. Res J Environ Sci 3 (3): 345-360.

Hendriyani IS, Setiari N. 2009. The chlorophyll content and growth in long beans (Vigna sinensis) under different water availability of water. J Sains \& Mat 17 (3): 145-150. [Indonesian] http: //eprints.undip.ac.id/2335/1/artikel_jsm_nintya.pdf

Hsu SY, Kao CH. 2003. Differential effect of sorbitol and polyethylene glycol on antioxidant enzymes in rice leaves. Plant Growth Regul 39: 83-90.

Indraswati DS, Zulkifli, Handayani T. 2015. Resistant test on upland rice (Oryza sativa L.) to drought stress induced by polyethylene glyco 6000. In: Hidayat B, Candra AA, Sarono,Sukaryana Y, Gusta AR (eds); Prosiding Seminar Nasional Swasembada Pangan-Percepatan Swasembada Pangan untuk Memperkuat Kemandirian dan Ketahanan Pangan Nasional. Politeknik Negeri Lampung, Lampung, 29 April 2015. [Indonesian]

Jamil MS, Endang N, Zulkifli. 2015. Chlorophyll content of vanilla (Vanilla plantifolia Andrews) plantlet result selection for resitant to drought stress by in vitro. In: Hidayat B, Candra AA, Sarono,Sukaryana Y, Gusta AR (eds). Prosiding Seminar Nasional Swasembada Pangan-Percepatan Swasembada Pangan untuk Memperkuat Kemandirian dan Ketahanan Pangan Nasional Politeknik Negeri Lampung, Lampung, 29 April 2015. [Indonesian]

Kumar RR, Karajoi K, Naik GR. 2011. Effect of polyethylene glycol induced water stress on physiological and biochemical responses in pigeonpea (Cajanus cajan L. Millsp.). Recent Res Sci Technol 3 (1): $148-152$

Li R, Guo P, Baum M, Grando S, Ceccarelli S. 2006. Evaluation of chlorophyll content and fluorescence parameters as indicators of drought tolerance in barley. Agric Sci in China 5 (10): 751-757.

Maisura, Chozin MA, Lubis I, Junaedi A, Ehara H. 2015. Rate of assimilation total and relative growth of drought-tolerant rice on paddy system. Jurnal Agrium 12 (1): 10-15. [Indonesian]

Meher, Shivakrishna P, Ashok RK, Manohar RD. 2018. Effect of PEG6000 imposed drought stress on RNA content, relative water content
(RWC), and chlorophyll content in peanut leaves and roots. Saudi J Biol Sci 25: 285-289.

Mescht A, Ronde JA, Rossouw FT. 1999. Chlorophyll fluorescence and chlorophyll content as a measure of drought tolerance in potato. South Afr J Sci 95: 407-412.

Nio SA. 2010. Evaluation of concentration of total chlorophyll, chlorophyll $\mathrm{a}$ and $\mathrm{b}$ in leave as indicators of water deficit in rice (Oryza sativa L.). J Ilmiah Sains 10 (1): 86-90. [Indonesian]

Nio SA. 2011. The biomass and leaf chlorophyll content in ginger (Zingiber officinale L.) under water deficit. J Ilmiah Sains 11 (1): 1-5. [Indonesian]

Nio SA, Banyo Y. 2011. Leaf chlorophyll content as indicators of plant drought tolerance. J Ilmiah Sains 11 (2): 166-173. [Indonesian]

Nio SA, Ludong DPM. 2014. Comparing the drought tolerance of local rice cultivar Superwin with other cultivars in North Sulawesi Province based on dry matter partitioning. Proc Int Conf Glob Resour Conserv 4 (1): 17-22.

Nio SA, Colmer TD, Wade LJ, Cawthray G. 2011. Osmotic adjustment and solutes accumulation in leaves of wheat (Triticum aestivum L.) during water deficit. J Math Sci 16: 43-48.

Nio SA, Ludong DPM, Wade LJ. 2018. Comparison of leaf osmotic adjustment expression in wheat (Triticum aestivum L.) under water deficit between the whole plant and tissue levels. Agric Nat Res 52: 33-38.

Pratiwi AR. 2016. Evaluation of polyethylene glycol (PEG) 6000 effect to induce in-vitro water deficit in plantlet of soybean (Glycine max L.) cultivar Tanggamus. [Thesis]. Universitas Lampung. Lampung. [Indonesian]

Prihastanti E. 2010. The chlorophyll concentration and growth of cocoa (Theobroma cacao) sprout under different water-deficit levels. Jurnal Bioma 12 (2): 35-39. [Indonesian]

Purwadi E. 2011. Pengujian ketahanan benih terhadap cekaman lingkungan. https: //www.duniapelajar.com/2011/05/23/pengujianketahanan-benih-terhadap-cekaman-lingkungan/.

Rahayu E, Ilyas S, Sudarsono. 2006. The in vitro selection of embryo somatic in peanuts grown in the medium with polyethylene glycol for water deficit simulation. Jurnal Biosfera 23 (1): 16-23. [Indonesian]

Ranjbarfordoei A, Samson R, Van Damme P, Lemeur R. 2000. Effect of drought stress induced by polyethylene glycol on pigment content and photosynthetic gas exchange of Pistia khinjuk and P. mutica. Photosynthetica 38 (3): 443-447.

Salisbury FB, Ross CW. 1992. Plant Physiology. 4 ${ }^{\text {rd }}$ ed. Wadsworth Publishing Company, California.

Sinaga E. 2015. The in vitro drought selection in sixteen strains of eggplant (Solanum melongena L.) using polyethylene glycol. Jurnal Hortikultura Indonesia 6 (1): 20-28. [Indonesian]

Sirait J. 2008. The leaf area, chlorophyll content and growth rate in grass under different shading and fertilization treatment. Jurnal Ilmu Ternak dan Veteriner 13 (2): 109-116. [Indonesian]

Sopandie D. 2013. Plant physiological adaptation response to abiotic stresses in the tropical agroecosystem. IPB Press, Bogor. [Indonesian]

Tal M. 1983. Selection for stress tolerance. In: Evan DA, Sharp WR, Ammirato PV, Yamada Y (eds) Handbook of Plant Cell Culture Vol 1-Techniques for Propagation and Breeding. Macmillan Publishing Co, New York.

Tao H, Brueck H, Dittert K, Kreye C, Lin S, Sattelmacher B. 2006. Growth and yield formation for rice (Oryza sativa L.) in the watersaving ground cover rice production system (GCRPS). Field Crops Res 95 (1): 1-12.

Tjolleng F, Siahaan P, Nio SA. 2019. The level of leaf total chlorophyll in North Sulawesi local rice under partial submergence. Jurnal MIPA UNSRAT Online 8 (2): 51-54. [Indonesian]

Wood AJ. 2005. Eco-physiological adaptations to limited water environments. In: Jenks MA, Hasegawa PM (eds). Plant Abiotic Stress. Blackwell Publishing Ltd, India. 